furter's suggestion would be limited to res ipsa loquitur cases. ${ }^{24}$ Better authorities agree that res ipsa loquitur is not a special "doctrine" but rather a rule of circumstantial evidence. ${ }^{25}$ If this is accepted, then all cases involving circumstantial evidence would seem to be within the scope of the proposal, and the administrative confusion engendered would blanket not only res ipsa loquitur cases but every conceivable field of litigation.

It may be thought that the modern trial judge should retreat from the traditional rigorously passive role of referee, but such reform should not be pressed without consideration of its practical effects. Although the perfect trial system would insist upon the production of all relevant facts, leaving substantive policy objectives to be openly expressed rather than effectuated through indirect "evidentiary" techniques, Mr. Justice Frankfurter's suggestion must be appraised in a realistic setting. Res ipsa loquitur as it has been developed represents an indirect judicial handicap in furtherance of a judicially approved social objective. It would appear that the Justice, while warning his brethren that "the radiating potencies of a decision may go beyond the actual holding," 20 has suggested an apparently evidentiary reform which, when applied to an imperfect legal system, entails substantive results running counter to contemporary currents of accident law, and which creates administrative problems far more serious than the malady it proposes to cure.

\title{
THE CORFU CHANNEL CASE: THE INTERNATIONAL COURT OF JUSTICE BIDS FOR EXPANDED JURISDICTION
}

When a court has compulsory jurisdiction it can impose the rigorous procedure of the adversary system without fear that the defendant will walk out; and it may properly consider any action begun by the unilateral filing of a complaint, or application, by one aggrieved. ${ }^{1}$ But where a court's jurisdiction, being non-compulsory, depends solely upon consent of the parties, the milder procedural characteristics of an arbitral or mediation tribunal may naturally

24. It is difficult to determine whether Mrr. Justice Franlfurter intended to limit his proposal only to res ipsa loquitur cases. Although discussing the particular res ipsa loquitur situation before the court, the Justice also speaks in more general terms of the judge's duty to be a functionary of justice rather than a mere referee. 333 U.S. 46,54 (1948).

25. "The majority of American courts regard res ipsa loquitur as nothing more than one form of circumstantial evidence." Prosser, Tosts 303. See also James, suspra note 13 , at 388 .

26. Hawks v. Hamill, $28 S$ U. S. 52, 58 (1933), quoted by Mrr. Justice Frankfurter in the instant case, 333 U. S. 46, 56 (1948).

1. For general details typical of an adversary system, see 1 Mroose's Fedsur PracTICE $\$ \$ 4.01-5.08$ (1938). Cf., for analysis of the nature of jurisdiction, 1 BLicr, JUnGMents $\$ \$ 215-244$ (1S91); Restateanent, Conflut of Laws $\$ \$ 42-97$ (1934); Beale, 
be expected; and these cases will be introduced by some bilateral agreement of the parties to submit specific areas of disagreement for settlement. ${ }^{2}$

Having areas both of compulsory and non-compulsory jurisdiction, ${ }^{3}$ the Permanent Court of International Justice had followed these practical dictates to evolve two different bodies of procedure, applied depending on the jurisdictional category of the case. When in 1945 the rules and precedents which the Permanent Court had evolved to solve the procedural complexities arising from its dual jurisdiction were given to the newly created International Court of Justice, ${ }^{4}$ the hope was that these were tools enough to work strccessfully within the twin areas of jurisdiction inherited from the old Court.

The new Court's first proceeding, however, the Corfu Channal Case, 5 has raised procedural questions to which the answers of the old court seemed neither clear nor presently efficacious. Specifically, when the Court was asked whether one party could assume the role of plaintiff and initiate an action by filing a unilateral application in a dispute not covered by the Court's compulsory jurisdiction, the new Court had to improvise. But having tempted the Court with novelty, the Corfu Channel Case raises a broader issue. By making some change in the traditional adversary and arbitral procedures has the patchwork of old and new resulted in a procedure inadequate to cover the variant needs of the Court's compulsory and non-compulsory jurisdictions?

On October 22, 1946 two British destroyers struck mines in the Corfu Channel off the Albanian coast. ${ }^{6}$ The United Kingdom charged that Albania

Jurisdiction of a Sovereign State, 36 HARv. L. REv. 241 (1923); Nussbaum, The Cizil Law Principles of Jurisdiction of Courts, in ChEatrans, Downrng AND Goodrich, Cases and Materiats on Conflict of Laws 109 (1936); Comment, 45 Yale L. J. 1100, 1235 (1936).

While the filing of a complaint may be considered the beginning of an action, jurisu diction remains inchoate until minimal requirements of process have been met. 1 Mookt's Federal Practice $\$ \$ 4.01-4.40$ (1938).

2. For general details typical of an arbitral or mediation tribunal, see Sturcis, Comarerctal Arbitratton and Awards 379-519 (1930).

3. The jurisdiction of the Court comprised all cases which the parties referred to it and all matters provided for in treaties and conventions in force. STATUTE of rilt Permanent Court of International Justice Art. 36. Cf. Statute of tue Interna* tronal Court of Justice Art. $36, \S 1$. For an account of the procedures consequent on the different types of jurisdiction, see p. 192 infra.

4. The International Court of Justice is the successor to the Permanent Court of International Justice, which functioned from 1922 to 1940 , the Statute and Rules of the old Court being retained almost verbatim, to make possible the utilization of its rich cxperience. Hudson, The Twenty-Fourth Year of the World Court, 40 As. J. INT'L L, 1 (1946).

5. I.C.J., Corfu Channel Case, Preliminary Objection, Judgment of March 25, 1948.

6. The incident arose against a background of tension. In April, 1946, the British severed diplomatic relations with Albania owing to the "unfriendly and uncooperative attitude adopted by the Albanian government," and later incidents included shelling of British ships by Albanian coastal batteries. The mine incident provoking the case arose when the British destroyers Saumarez and Volage struck mines off the Albanian shore. 
had unjustifiably laid the mines, and after failing to obtain satisfaction, ${ }^{7}$ filed an "application", or complaint, with the Court. Albania in a letter to the Court alleged that the tribunal had no jurisdiction but stated, inter alia, that she still wished to have the Court decide the case. ${ }^{8}$ But when the Court proceeded, Albania in a preliminary objection ${ }^{0}$ questioned the Court's authority

Both managed to reach port in Corfu, but the Sammars was damaged beyond repair, while the Volage was badly crippled, and forty-four officers and seamen were lilled.

Minesweeping operations by the Royal Navy on November 12 and 13 revealed a sizeable newly-laid minefield. For a full account of the incidents, see Security Council, Official Records, Supp. No. 6 (Feb. 18, 1947) (United Kingdom exhibits); id., No. 16 (Feb. 19, 1947) (Albanian statement); id., Supp. No. 10 (MIar. 20, 1947) (report of Security Council subcommittee).

7. The British stopped direct negotiations when the Albanian reply to their note declined the demand for reparation and an apology, refused responsibility for the incidents, and (1) complained that the British attitude was "unfriendly," (2) asserted thast the British warships in question had entered Albanian territorial waters without authority and demonstratively, (3) rejected the accusations as "completely without found3tion" and as "profoundly wounding to the peaceful aspirations and feelings of the Albanian people and the Albanian Government," and (4) insinuated the Greels had laid the mines to cause trouble.

The United Kingdom then brought the dispute before the Security Council, which invited Albania to participate in the discussion on condition that she accept all the obligations of a member of the United Nations. Security Council, Official Records, Supp. No. 3 (Jan. 20, 1947) ; Security Council, Official Records, No. 6 at 123 (Feb. 18, 1947). For Albania's acceptance, see Security Council, Official Records, No. 7 at 130-1 (Feb. $28,1947)$. On March 25 the U. S. S. R. vetoed the amended British resolution, which stated that the minefield could not have been laid without the knowledge of the Albanian authorities. Security Council, Official Records, No. 15 (Feb. 18, 1947) (discussion in Security Council); id., No. 16 (Feb. 19, 1947) (same); id., No. 18 (Feb. 24, 1947) (same); id., No. 21 (Feb. 27, 1947) (same); id., No. 27 (Mlar. 20, 1947) (same); id., No. 28 (Mar. 21, 1947) (same) ; id., No. 29 at 609 (Mar. 25, 1947) (British resolution defeated). On April 9 the Security Council, acting in accordance with Article 36 of the Charter, adopted a resolution recommending that the dispute be referred to the Court. The vote was eight to nothing in favor of adoption, the U. S. S. $R$ and Poland abstaining, and the United Kingdom, as a party to the dispute, not having a vote. Sceurity Council, Official Records, No. 34 at 719-27 (April 9, 1947).

8. For text of the Albanian letter see I.C.J., Corfu Channel Case, Judgment of Mfar. 25, 1948 at 18-9. Of possible significance is the fact that Albania wrote this letter at a time when she was striving to become a member of the United Nations. One of the questions under consideration by the United Nations Committee of Admissions was whether Albania intended to accept her obligations, and specifically, whether she intended to carry out the Security Council resolution of April 9 (see note 7 supra). A copy of Albaniz's reply to the Court was received, and was interpreted as consenting to the Court's jurisdiction. Security Council, Official Records, Spec. Supp. No. 3 at $48,30-6$ (1947). Nevertheless, Albania's application for membership was denied on August 18, 1947. United Nations Press Release SC/347 (August 18, 1947).

9. I.C.J. Drstr. 180, General List No. 2 (1947). The objection was in accordance with Article, 62 of the Rules of Court, which further provides that the Court may decide on the preliminary objection immediately after hearing the arguments, or it may defer decision until after the merits have been argued, and pass on both by a single judgment. For cases in which the Permanent Court joined the objections to the merits, see, c.g., Cases of Pajzs, Csáky and Esterházy, P.C.I.J., Ser. A/B, No. 66 and No. 6S (1936); 
to hear the case, alleging that the application was ineffective since there was no basis for compulsory jurisdiction, ${ }^{10}$ and since formal requirements of an agreement to submit a specific dispute had not been fulfilled.

Although the Court was able to avoid deciding the issue by stustaining its jurisdiction on a non-compulsory basis, the case of the United Kingdom rested in large part on the argument that incidents prior to application had established compulsory jurisdiction in the tribunal.11 When the dispute first arose, the United Kingdom submitted it to the Security Council which, failing to resolve the issue, recommended that the dispute be brought to the International Court of Justice. By combining Article 25 of the Charter, which provides that all members shall obey "decisions" of the Security Council, and Article 36, which empowers the Council to "recommend" that a dispute presented to it be referred to the Court, the United Kingclom argued that the Court had compulsory jurisdiction. ${ }^{12}$ This equating of "recommendation" under Article 36, with "decision" under Article 25 would make reference by the Security Council binding, and would create a compulsory jurisdiction ap-

Case Concerning the Administration of the Prince von Pless, P.C.I.J., Ser. A/B, No. 52 at 16 (1933).

10. At no point did the parties or the Court contend that the case was covered by any of the traditional bases of compulsory jurisdiction, i.e., treaties or conventions in force. However, the British did argue for a novel compulsory jurisdiction, discussed in succeeding text.

11. The fact that the United Kingdom made an argument for compulsory jurisdletion would indicate that she thought an application could not be filed without such a basis. This assumption is strengthened by Article 32 of the Rules of Court, which requires an application to state, "as far as possible, ... the provision on which the applicant found the jurisdiction of the Court."

12. A literal reading of Article $36(1)$ of the Statute would seem to give support to the British argument: "The jurisdiction of the Court comprises all cases which the parties refer to it and all matters specially provided for in the Charter of the Utited Na. tions or in treaties and conventions in force." (Emphasis supplied.) The italicized words were added in a draft by the Washington Conference of Jurists and there is nothing in the Charter to which they can refer except Article 36, which deals with the Security Council's power to recommend referral of disputes to the International Court of Justice. Cf. Security Council, Official Records, No. 34 at 722-7 (April 9, 1947) (the Security Council votes on the referral with the apparent interpretation that their action makes the Court's jurisdiction compulsory).

But actually the phrase has no reference-it was added in case the San Francisco Conference should make some extension of the Court's jurisdiction. Nineteenth Meeting of Committee IV/1, Doc. No. 828, 13 U. N. CoNF. Doc. 282, 284 (1945). It remained because of inadvertence in the haste of the last weeks of the Conference. Hudson, Thic Twenty-Fourth Year of the World Court, 40 AMr. J. INT'L L. 1, 32 (1946); Preuss, The International Court and the Problem of Compulsory Jutrisdiction, 13 Dep'T of State Bull. 471 (1945). That the Charter does not permit compulsory referral, seo United Nations Conference on International Organization, documents cited note 14 infrai Exec. Rep. No. 8, Senate, 79th Cong., 1st Sess. (1946) (Report on Charter by the Foreign Relations Committee of the Senate); Eagleton, The Jutrisdiction of the Sccurily Couticil over Disputes, 40 AMr. J. INr'L L. 513, 514, 516, 529 (1946). 
plicable to all members of the United Nations, whether or not they had previously accepted the Court's jurisdiction. ${ }^{13}$

Although eight of the justices reserved opinion on this British proposal, its flat rejection in a concurring opinion by the remaining seven permanent members of the Court makes future success for the British interpretation of Articles 25 and 36 seem doubtful. While this result may be lamentable in that it restricts the power of the Security Council in the pacific settlement of disputes, it must be remembered that in diplomatic language "recommendation" is never synonymous with "decision." Moreover, the San Francisco Conference expressly rejected proposals to give the Court compulsory jurisdiction over all United Nations members. ${ }^{15}$

But if the Court was unwilling to seize compulsory jurisdiction, it was enger to accomplish the same result by a reconstruction of the traditional methods of invoking its non-compulsory powers. All fifteen permanent judges ${ }^{10}$ denied

13. All members of the United Nations are ipso facto parties to the Statute of the International Court of Justice. U.N. Crarter Art. 93(1). But to date 29 of the 58 members have not made the optional declaration, provided for in Article 36(2) of the Statute, recognizing the Court's jurisdiction as compulsory in relation to any other state maling the same declaration. Jurisdiction through compulsory referral would also apply to any non-member like Albania, who, for the purpose of settling a particular dispute, agreed to accept all the obligations of a member. Even an attempted reservation in an optional declaration would not prevent jurisdiction arising from referral by the Security Council.

14. The recommendations of the Council of the League of Nations had no binding force. Treaty of Lausanne, P.C.I.J., Ser. B, No. 12 at 27-S (1925); Bẻnes, Scetrily ard Reduction of Armaments, 7 World Peace Foundation Pasprelets 441, 445-6 (1924); Larnaude, La Société des Natrons 37 (1920). Considerable attention was given at San Francisco to the legal effects of "recommend" as used in Article 36 of the Charter. That it possessed no obligatory effect, see Seventh Meeting of Committee III/2, Doc. No. 433, 12 U.N. Cons. Doc 47, 48 (1945); Ninth Mieeting of Committee III/2, Doe. No. 498, 12 U.N. Conf. Doc 65, 66 (1945); Twelfth Afeeting of Committee III/2, Doc. No. 992, 12 U.N. CoNF. Doc. 105, 108-9 (1945) ; Fourteenth Mleeting of Committee III/2, Doc. No. 1029, 12 U.N. Conf. Doc. 134, 137 (1945); Third Mleeting of Commission III, Doc No. 1088, 11 U.N. Conf. Doc. 80, 84 (1945). Cf. Goodrici arid Hassoro, Criatter of the United Nations, Comarentary and Docusrentis 122, 150 (1946).

15. The members of the Washington Committee of Jurists had been divided on the question of compulsory jurisdiction and so had submitted Article 36 of the Statute to the San Francisco Conference in two texts, the alternative being the "optional compulsory jurisdiction" of the old Court. DRaft of Statute of aN Intersiatjosial Couts of JusTICE, submitted by the United Nations Committee of Jurists to the United Nations Conference on International Organization, Jurist 59, 14 U.N. CoNr. Doc 547, 357 (1945). Opposition by the United States and the U. S. S. R. defeated compulsory jurisdiction. Second Meetiris of Commission IV, Doc. No. 1007, 13 U.N. Corrs. Doc. 53, 56-7 (1945).

16. The opinion of the Court was signed by the following eight permanent members: Guerrero, El Salvador; Hackworth, U.S.A.; Fabela, Mfexico; MicNair, England; Klacstad, Norway; Read, Canada; Hsu Mo, China; Azwedo, Brazil. Seven judges-Basdevant, France; Alvarez, Chile; Winiarski, Poland; Zoricic, Yugoslavia; de Visscher, Belgium; Badawi Pasha, Egypt and Krylov, Russia-joined in a concurring opinion.

Dr. Igor Daxner, ad hoc judge from Czechoslovalia, appointed in accordance with Article 31 of the Statute, agreed that the absence of a compromis was not fatal, so the 
Albania's plea that the Court follow the precedent of receiving unilateral applications only in cases of compulsory jurisdiction and of accepting stibmission of all other disputes only by formal compromis. Stating that a stibmission could be given by any acts which taken together expressed the consent of the parties, the Court ruled that a unilateral application could be filed by a complaining nation in any case; and that if jurisdiction were non-compulsory, submission could be perfected by a consenting reply from the accused state. By this liberal definition of submission, the Court has refused to limit either of its two categories of jurisdiction to specific methods or formalitics of initiating the action, thus advancing considerably from precedents of the old Court. ${ }^{17}$

But the Corfu Channel Case has left the Court with serious and unsolved legal problems. For both the old Court's precedents and rules, and the rules of the new Court allow the method of initiation to dictate subsequent trial procedure. ${ }^{18}$ By blurring these traditionally distinct forms of initiation, the Court is left with the task of redefining those procedural incidents of trial formerly determined by the mode of initiating suit. ${ }^{19}$ For example, cases initiated by compromis have traditionally been limited by the Court to those issucs formulated in the special agreement, while in cases begun by application, the claimant has been free in both written and oral stages to depart from issucs raised in its application. ${ }^{20}$ While subsequent development in the Corf $u$ case

Court was unanimous on this aspect of the case. He dissented, but only on the grount that the Albanian letter, correctly interpreted, did not give consent to the United Kingdom application.

17. For statements that Article 40 of the Statute required a special agrecment it all cases not subject to compulsory jurisdiction, see Revision of the Rules of Court, P.C.I.J., Ser. D, Addendum to No. 2 at $176 \mathrm{et} \mathrm{seq.} \mathrm{(1926)} \mathrm{;} \mathrm{Elaboration} \mathrm{of} \mathrm{the} \mathrm{Rules} \mathrm{of}$ Court, P.C.I.J., Ser. D, Third Addendum to No. 2 at 139, 157 (1936) (difference be. tween application and special agreement); Preparation of the Rules of Court, P.C.I.T., Ser. D, No. 2 at 201-2 (1922) (an application can be used only where there is compulsory jurisdiction); Ninth Annual Report, P.C.I.J., Ser. E, No. 9 at 65 (1933) (whare there is no compulsory jurisdiction, to bring the case validly before the Court notice of the special agreement must be given by all the parties, unless the special agreement itsclf provides otherwise); Hudson, Permanent Court of International Justice 168 (1934); Hammarskjöld, 1927-II ANNUAIRE de L'INSTITUT DE Drolt INTERnatowat. 821 (1927). While the Permanent Court had said previously in Rights of Minorilies in Upper Silesia that its jurisdiction was "not ... subordinated to the observance of cer. tain forms, such as, for instance, the previous conclusion of a special agreement," the holding was merely that an issue previously validly submitted under compulsory jurisdic. tion could be extended by the parties during the trial, and the statement drew strong dissent. Rights of Minorities in Upper Silesia, P.C.I.J., Ser. A, No. 15 at 2 $3,52,57,69-70$ (1928). For the same result, cf. Mavrommatis Jerusalem Concessions, P.C.I.J., Ser. A, No. 5 (1925).

18. Cf. Lighthouses Case Between France and Greece, P.C.I.J., Ser. A/B, No. 62 at 6-7 (1934); Legal Status of South-Eastern Territory of Greenland, P.C.I.J., Ser. A/B, No. 55 (1933).

19. See note 22 infra and note 18 supra.

20. If the respondent objects, the Court is left without jurisdiction to adjudicate on the new submissions, but if the respondent does nothing or submits arguments on tho 
has not yet posed this problem for the Court, it is significant that the justices have adhered to other procedural rules in this action once incident only to cases begun by application. ${ }^{21}$ Here, the United Kingdom has been given the role of injured plaintiff and allowed to advertise its status as aggrieved party. In contrast, when bilateral submission formed the basis of jurisdiction, as in the Carf $u$ case, the Court formerly had required simultaneous written presentation and oral argument by alphabetical order. ${ }^{22}$

There is no valid reason for permitting the realistically significant incidents of trial procedure to be determined by the mechanical mode of initiating the action. No harm is done, of course, where the mechanical modes are directly geared to the realistically relevant considerations. But when the Court no longer considers the form of initiation to depend directly upon its jurisdictional source, it becomes dangerous to continue to make all procedure dependent upon the mechanical form of initiation. Trial procedure should reflect an analysis both of what is fair for the parties in view of the Court's source of jurisdiction, and of what tends for efficiency in the Court's operation. It seems desirable to define "agreement" liberally and thus allow applications to be received as one of the statements of consent necessary to invoke that jurisdiction resting only on bilateral agreement. But it would seem unfair then to give such an "applicant" the full status of plaintiff, or to allow the Court to follow an adversary procedure as though the case were within the Court's compulsory jurisdiction merely because the mode of case initiation had included an "application." The critical importance of these procedural issues can hardly be overstated, since the success of the Court must ultimately rest on the goodwill and respect which its manner of handling disputes engenders among nations.

Certainly the Corfu rule points a quick way around the tedious requirements of a special agreement in cases lacking compulsory jurisdiction. And though

merits or asks for.a decision on the merits, then the Court has jurisdiction over the new submissions. Case of the Société Commerciale de Belgique, P.C.I.J., Ser. A/B, No. 78 at 174 (1939); cases cited note 17 supra; Scerni, La Procédure de la Cour formonente

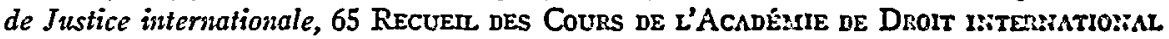
DE LA HAYE 560,626 (1938).

21. The Court in its Judgment of March 25 ordained time limits for the filing of subsequent written pleadings which allow the applicant, the United Kingdom, to present its arguments first. The United Kingdom is being given priority in the oral proceedings also. This type of procedure is characteristic of the adversary system; one party is given such priority in cases of non-compulsory jurisdiction only where the special agreement so provides. Cf. note 22 infra.

22. Rules of Court Art. 41 ; id., Art. 51 ; Brazilian Federal Loans Case, P.C.I.J., Ser. A, No. 21 at $94-7$ (1929) and P.C.I.J., Ser. C, No. 16-IV at 10 (1929); Case of Free Zones of Upper Savoy and District of Gex, P.C.I.J., Ser. A, No. 22 at 5-7 (1929), P.C.I.J., Ser. A at 4-9 (1930) and P.C.I.J., Ser. C, No. 17-I at 10 (1929); Preparation of the Rules of Court, P.C.I.J., Ser. D, No. 2 at 72 (1922); Scerni, op. cit. supra note 20, at 630-40; INSTITUT FÜR AUSLÄNDISCHES OFFENTLICHES REcht UND VôlRERrecht, Statut et RÈglement de La Cour peraranente de Justice miternatto:iale $295 \mathrm{ct} s c q$. (1934). 
the way may not be followed, the right to file an application under the Corf 1 practice brings the full pressure of publicity to urge a recalcitrant state to consent to the Court's jurisdiction. It is true that a cited state may always refuse to give consent and thus avoid the disadvantages accruing from institution by application; but to ignore the application entirely might be considered a flouting of the Court on the part of the cited state. The answering state might tenably take the position that although it does want a hearing, the procedural prejudice of an adversary proceeding makes it impossible to accept the Court's jurisdiction. But if this stand is taken the accused nation is vulnerable to an on-the-spot offer of a compromis, the refusal of which would discredit its protestation of willingness to put the case before the Court. ${ }^{23}$

The lapse from law to legalism so prevalent in some of the political organs of the United Nations has been successfully avoided in the first decision of its judiciary. But even in congratulating the Court for its realism a note of calltion must be sounded: if its liberal interpretation of modes of initiating action extends the new Court's compulsory or non-compulsory jurisdiction beyond the limits of real member-consent, it may undermine that very trust and goodwill upon which the Court's existence depends. But if the Court applics its new rule with moderation and if it has successfully gauged the real tenor of member-nation feeling, the case may introduce a way to greater use of legal processes for the peaceful settlement of international disputes.

23. During the trial of the Corfu Channel Case the United Kingdom repeatedly offered to conclude a special agreement with Albania, and on the day the judgment of the Court was delivered, such a compromis actually was announced by the representatives of the Governments of the United Kingdom and Albania. 4 U.N. BuLL. 335 (1948). 